\title{
APRESENTAÇÃO DE “CIVILIZAÇÃO DOS INDÍGENAS. DUAS PALAVRAS AO AUTOR DO MEMORIAL ORGÂNICO", DE MANUEL ANTÔNIO DE ALMEIDA
}

\author{
Cilaine Alves Cunha
}

Em “Civilização dos indígenas" (1851), Manuel Antônio de Almeida concretiza uma contundente discordância do Memorial orgânico (1849-1850), de Francisco Adolfo de Varnhagen. Oferecido “à consideração das assembleias gerais e provinciais do Império", o texto de Varnhagen surge em meio aos debates políticos desencadeados pelas revoluções oitocentistas, especialmente a de Pernambuco (1848), e pela previsão do fim do tráfico negreiro com a promulgação da Lei Eusébio de Queirós (1850). Advoga-se então a urgência de uma ação governamental que garanta a unidade territorial do país, consolide o controle, pelos dirigentes monárquicos, da gestão do Estado nacional, a centralização na corte dos rumos políticos do país e do poder de regular as normas do direito.

O Memorial orgânico propõe uma ação voltada para reorganizar o território nacional e a força de trabalho. Pretende melhor redistribuir o espaço territorial por departamentos, expandir o número disperso de habitantes pelas áreas ociosas do país, definir com precisão suas fronteiras com as nações vizinhas, transferir a capital nacional para a região central e criar comunicação que ligue o norte e o sul, o litoral e o interior.

O autor do Memorial não se opunha à escravidão, mas pensava que sua preservação oferecia danos à "nação". Entre os principais fantasmas que assolavam a elite patrimonialista, a revolta do Haiti e o aumento da população afrodescendente geravam o receio de insurreição dos escravos. Para afastá-lo, Varnhagen aconselha o estímulo à imigração da mão-de-obra estrangeira. Declarando guerra ao aborígene, também detrata a mitificação literária em curso da cultura indígena.

O retrato que o autor traça das "raças bravias" compõe a imagem do bárbaro moralmente incapacitado, ladrão de terras da civilização. Para desbravar o índio, restaria, nessa ótica, recuperar a prática das bandeiras. Caçado e laçado, ele deveria permanecer por quinze anos sob o regime de protetorado ou tutela de um senhor que o catequizasse, educasse e domesticasse.

Nesse texto de estreia como cronista de jornal, Manuel Antônio de Almeida concentra-se exclusivamente no último tópico do Memorial orgânico. A linguagem perplexa 
e enfática da indignação traduz tutela por castigo, tronco, chicote e marcas corporais de violência. "Civilização dos indígenas" acusa Varnhagen de disfarçar a institucionalização do sadismo sob o regime de proteção. Sua oposição desde cedo ao modo de produção escravista emerge ainda do paralelo que estabelece dos métodos bárbaros do tráfico e dos navios negreiros com as bandeiras.

Um diagnóstico crítico da vida social do país, disseminado pelos oposicionistas nesse momento anterior à conciliação com os conservadores, determina as relações humanas de Memórias de um sargento de milícias e já pode ser observado em "Civilização dos indígenas". A compreensão entre os liberais de que o Brasil poderia manter-se distante de um estágio evolutivo da história da humanidade, perpetuando um modo de vida precário e práticas sociais desumanas e belicosas, apresenta-se nesse texto como um dos fortes argumentos contra a escravidão indígena.

Manuel Antônio de Almeida fala do lugar dos princípios liberais, em favor da sociabilidade, da fraternidade, da civilização e de um acordo entre etnias em luta. Em contrapartida, aproxima Varnhagen dos colonizadores e capitães donatários, identificados com ganância e rapinagem que tomam de assalto as terras do aborígene.

Entre as razões de Almeida contra a servidão indígena, uma delas se projeta sobre a escravidão em geral. $\mathrm{O}$ artigo descreve um cenário social em que ela acirra a luta civil e dissemina a violência pelas diferentes camadas da população: pelo escravo e pobre livre, candidatos prováveis a bandeirantes que, adquirindo o poder de prender e matar, poderão tornar-se senhores do cativeiro; pelo fazendeiro, o chefe do bando que se coloca acima das autoridades constitucionais e da lei, reafirmando a instituição do senhor feudal.

Quando escreveu “Civilização dos indígenas", Manuel Antônio de Almeida cursava o segundo ano de Medicina. O artigo foi originalmente publicado no jornal oposicionista Correio Mercantil, pouco antes de o autor empregar-se aí por alguns anos, durante os quais editará nesse periódico seu único romance. Em fevereiro de 1852, o Jornal do Comércio reproduz o texto. Desde então, foi reeditado em 1991, na Obra dispersa do autor (org. Bernardo de Mendonça, Graphia).

Varnhagen, por sua vez, já era membro do Instituto Histórico e Geográfico Brasileiro quando publicou o Memorial orgânico, antes de se tornar o principal historiador do Segundo Reinado com a História geral do Brasil (1854). O texto foi anonimamente divulgado em Madri em dois volumes. Em 1851, pôde ser lido nas páginas da revista Guanabara, organizada por Manuel Araújo Porto Alegre, Gonçalves de Magalhães, Joaquim Manuel de Macedo e Gonçalves Dias. 


\section{Civilização dos indígenas. Duas palavras ao autor do Memorial orgânico}

Manuel Antônio de Almeida

En maintenant l'unité de l'espace humaine, nous rejetons, par une conséquence necessaire, la distinction désolante de races supérieures et de races inférieures. Sans doute il est des familles plus susceptibles de culture, plus civilités, plus eclarées; mais il n'en est pas de plus nobles que les autres. Toutes sont également faites pour la liberté...

Cosmos, Humboldt

Um grito de guerra, bem pouco generoso, contra as raças indígenas do Brasil, acaba de ser levantado pelo autor de um trabalho intitulado Memorial orgânico - publicado nas páginas do Guanabara; um grito de guerra, que parece ser o eco daquele que ao pôr pé no território brasileiro fora soltado pela cobiça dos Portugueses.

Julgávamos que a questão relativa aos nossos indígenas se achava de muito resolvida; julgávamos que não havia mais filósofo de qualquer seita, político de qualquer cor, que não acreditasse que o único meio de fazer servir esses homens à humanidade, a Deus, e ao Estado é acabar para sempre com esse sistema de tirânica opressão, que tanto tem pesado sobre eles, que tem conseguido esmagar-lhes famílias inteiras; pensávamos que todos aqueles meios estúpidos, atrozes, inconsequentes, com que se pretendia outrora domar o nosso gentio, haviam acabado com a barbárie dos tempos coloniais; que dessa época só havíamos guardado para esse fim a cruz de Anchieta e a palavra de Nóbrega. Enganávamo-nos! Ainda há quem venha restabelecer os hábitos da barbaridade passada, adoçados ou esquecidos pela civilização presente; ainda há alguém que, descrendo impiamente da força da palavra, do poder da religião, do influxo da civilização, ouse ir desenterrar a espada de Mem de Sá, o Devastador dos Tamoios, e dizer-nos: "Eis aqui a civilizadora das raças indígenas".

Vale a pena de nos ocuparmos por um pouco com esta importante questão; deixaremos de parte tudo mais que nesse trabalho diz o autor, e ocupar-nos-emos unicamente deste ponto. 
É no capitulo "População e colonização" que o autor começa. Como Bacon e Descartes, que desaprenderam primeiro a filosofia que sabiam, para depois formarem o seu sistema, quer o autor desaprender primeiro tudo o que sabe a respeito da matéria, para depois apresentar suas novas ideias; aspira à originalidade. Vejamos primeiro o que é que o autor aprendeu, ou deve ter aprendido e agora quer esquecer, e depois veremos o que apresenta de novo.

Da religião aprendeu o autor que ensinar aos que ignoram é um santo dever; que devemos utilizar e não destruir as obras de Deus; que o homem deve ajudar aos mais ignorantes com a sua inteligência, assim como aos mais fracos com o seu braço. Da marcha da humanidade, da civilização, da história, aprendeu o autor que o homem lucra com a conservação do homem; que os hábitos de guerra tornam ásperos os costumes dos povos; que o meio mais seguro de conquista é a força da inteligência; que o homem se enobrece quando a põe em exercício, que ele apura os seus conhecimentos e crenças, quando os reparte com os outros. Tudo isso aplicado à questão dos indígenas dá em resultado que devemos antes de tudo procurar com ardor, com afinco, catequizá-los, aproveitá-los no serviço de Deus, repartir com eles a nossa ilustração, a nossa indústria; domarmos-lhes o gênio belicoso com exemplos de paz, atraí-los enfim a nós pelo meio que mais poder exerce sobre o homem, qualquer que seja o seu estado, a segurança de liberdade. É isso o que o autor deve saber, porque é isso o que todos sabem; tudo o mais a respeito está proscrito e desprezado. É isto portanto o que o autor quer esquecer; quer esquecer a humanidade, a religião, a história... tudo por amor de mais cem ou duzentas léguas de território de que poderemos dispor, e que tanto ciúme Ihe causa ver nas mãos do gentio, que nelas nasceu, e que nelas vive desde muito antes que lhe soubéssemos nós da existência!

Vejamos agora o resultado novo que apresenta o autor depois de ter desaprendido tudo isso. É muito simples; é mesmo consequente: o autor quer de hoje em diante para os indígenas a guerra e a escravidão! A guerra, apoiado em não sei que direitos herdados dos Normandos, pede-a ele em termos claros e precisos; a escravidão, apesar de a julgar lícita, vem disfarçada com o nome de tutela. Mas isso que quer ser novo é velho e muito velho, mesmo mais do que aquilo que o autor repele como teorias sediças de filo-tapuias; isso é o que forma a história sanguinolenta do domínio espanhol e português na América; é essa a linguagem dos escritores e pensadores daquele tempo. Parece que o autor se deixou levar pela leitura dessas crônicas em que se faz de Pizarro um herói e de Cortez um filósofo humanitário. É essa a linguagem copiada das cartas e arengas dos capitães-mores do Estado do Brasil. Não há pois originalidade no que 
diz o autor, senão repetição de coisas muito sabidas e muito reprovadas. Entretanto, mesmo porque são coisas muito combatidas, é que a sua sustentação cumpre que seja altamente estranhada.

Quando, por toda a parte, fatigados pelas lutas materiais a que se tem arrojado a humanidade, os políticos e os filósofos invocam a fraternidade como meio de conciliação; quando no meio do tumultuar desabrido dos movimentos recentes da Europa se forma um congresso que hasteia a bandeira da paz, é impiedade vir entre nós, também feridos, também martirizados pelos golpes das revoluções, tocar um alarme de guerra. E sobretudo é isso cruel, porque a guerra que se pede não tem por causa motivo algum generoso e nobre; não tem por fim senão o sórdido e material interesse de adquirir mais algumas léguas de território, como se não o tivéssemos nós em quantidade capaz de satisfazer a mais desenfreada cobiça!

Quando depois de alguns anos de combate tivermos conseguido conquistar, ou antes destruir esta ou aquela tribo indígena, ganharemos, é verdade, mais um pedaço de terra; porém, quanto teremos perdido em moralização, em doçura de costumes, em hábitos de humanidade? Acha o autor que ainda não estamos bastante embrutecidos com as nossas revoluções políticas? Assenta que a ideia do apelo à força material, como meio de resolver todas as questões, ainda não está bastante enraizada no país? Temos tido até aqui bastantes guerras em nosso seio, porém têm sido todas entre partes de forças mais ou menos iguais; o autor quer dar-nos agora um espetáculo a que não estamos habituados; quer o massacre, a guerra do forte contra o fraco, do armado contra o inerme, da arte contra o instinto, do fuzil experimentado contra o tacape selvagem.

Quando os Portugueses aportaram ao Brasil toda a sua extensão se achava coberta de imensas tribos de selvagens; parece incrível: quando se ajuntavam para algum combate, ou para outro qualquer fim, diz uma testemunha ocular que pareciam tantos quanto as folhas das árvores. Entretanto, apesar do número, raras vezes foram os primeiros a romper hostilidades; entretanto, apesar da reputação de infidelidade que Ihes emprestam, guardavam muitas vezes de um modo muito nobre a fé dos tratados e promessas. Os Portugueses, porém, vinham a buscar riquezas, e não a trazer civilização; desprezaram essas boas inclinações; trataram de matar os indígenas para lhes tomarem as terras; mataram muito, e em número espantoso. De cada vez que precisavam de algumas léguas de terra para fundar uma capitania faziam um Saint Barthélemy e no outro dia tinham o que queriam e ainda mais uma centena de escravos, os prisioneiros do combate. Assim progrediram em toda aquela série de torpezas que dói comemorar. Não se pode pois falar em brandura empregada com os índios sem mentir a história. 
Dois, três ou quatro missionários constituíam toda a força moral com eles empregada; esses mesmos tinham que lutar com a má vontade dos donatários das terras, e de toda aquela caterva de sentenciados e aventureiros que Ihes faziam honroso cortejo. Quando o jesuíta trazia do meio dos bosques algum índio convertido, o donatário do lugar o arregimentava logo no número de seus escravos; o pouco que a fé fazia por um lado, desfazia-o por outro a avareza. Nós modernamente, se não seguimos a barbaridade de uns, também não imitamos a dedicação de outros; temos nos conservado em um estado de completa inação; catequeses, missões, tudo isso hoje é nominal; os governos têm pela maior parte desprezado completamente a questão. Não sabemos portanto de que experiência de meio século fala o autor para provar a insuficiência dos meios brandos; esses nunca foram, nem são empregados senão em uma escala tão acanhada que não pode ser levada em conta.

Se a história dos fatos não serve para justificar o que pretende o autor, o exame dos direitos está no mesmo caso. Não serve para justificar a guerra aos indígenas o alegar-se que são gente nômade e sem assento fixo, porque enfim, ainda que isso fosse absolutamente verdadeiro, há de haver na terra um lugar para eles, que como nós têm direito à vida e à subsistência. É também sofisma dizer-se que eles constituem uma revolução armada dentro do império, desobedecendo ao nosso chefe e à nossa lei! Quando se criou o império, o chefe e a lei, já eles ocupavam os lugares que ocupam e viviam a vida que vivem; o império, o chefe e a lei foram criados debaixo dessas condições. Como pois pode dizer-se que eles constituem uma revolução dentro do império? As nossas leis nem eles as juraram, nem mesmo sabiam delas, mas o autor diz que para o crime não vale em direito a alegação de ignorância. Ora, não há compêndio de moral que não consagre este princípio: - quando um indivíduo não sabe o que faz, o ato não lhe é imputável.

Tudo isso que acabamos de dizer serve para combater o princípio absoluto de fazer-se guerra aos indígenas; e como o autor se encarregou depois de indicar o modo por que a guerra deve ser feita, diremos também alguma coisa sobre isso, ainda que seja uma questão prejudicada por ter caído a primeira.

O autor pede o restabelecimento das bandeiras; isto é, quer dar, a qualquer que disso tenha vontade, o direito de armar-se e partir em uma correria sanguinária a buscar no meio dos bosques quem trabalhe em sua fazenda, ou quem sirva em sua casa. O mesmo que se vai hoje praticar-se na costa d'África quer o autor que se pratique dentro do império. Hoje um capitalista ambicioso tripula um navio e manda-o, à custa de muitos riscos e trabalhos, buscar uma centena de negros em Guiné; todos sabem 
até que ponto chega o embrutecimento dos que se empregam nesse cruel trabalho, todos os horrorosos padecimentos a que eles sujeitam esses infelizes, vítimas da cobiça: amontoados no estreito porão de um navio, homens, mulheres, velhos e crianças, todos os dias durante a viagem o mar recebe uns tantos que a nostalgia, a fome, a sede, a falta de ar, porque tudo sofrem eles aí, entregaram à morte; e não é só os mortos, que muitos recebe: se o navio periga, se ao longe no horizonte aparecem as velas do cruzeiro, se escasseiam os alimentos, abre-se a escotilha, e o navio lança ao mar às vezes quase toda a sua carga!... Pois bem, alguma coisa que bem se parece com isso há de produzir-se com o restabelecimento das bandeiras. Para tripular um navio negreiro é mister empregar um grosso capital com o risco de o ver perdido pelo cruzeiro; para armar uma bandeira basta juntar cem homens, mesmo escravos, cem ambiciosos, cem vadios, porque ninguém que o tenha deixará seu emprego para ir a essa horrível caçada de gente e partir... partir sem medo de cruzeiros, partir com carta de marca ou autorização da presidência, porque não quer o autor, para maior escândalo, que falte a essas levas de sangue o caráter oficial! Chegando a uma aldeia de índios essas caravanas de destruição, armadas com armas superiores e com a sede da cobiça, surpreendem ordinariamente de noite esses incautos no meio do sono; caem sobre eles; destroem, matam... matam cem para colher um prisioneiro, porque é sabido que se não entregam eles com facilidade, senão que lutam com esforço até a morte. Regressam depois com os despojos da carnificina; isto é, meia dúzia de prisioneiros; são estes sempre escolhidos entre os mais moços e robustos, que os velhos e as crianças, que para pouco serviriam, ou os matam, ou os deixam abandonados. Pelo caminho, se alguns deles buscam livrar-se das cordas que os amarram, vigorosos azorragues buscam submetê-los; se persistem, como é natural a homens da têmpera de um índio, um tiro na cabeça ou uma facada no coração põe tudo em tranquilidade! Quantas vezes depois de muito matar e muito destruir volta a bandeira sem um só prisioneiro!?

É esta a história sabida; nem dela precisávamos; basta o simples bom senso para ver que tudo isso é muito consequente, que isso mesmo é o que deve suceder. Uma guerrilha composta até de escravos grosseiros e brutais, que acharão sem dúvida um cruel prazer em ter também o direito de matar, castigar, prender, em ser também, ainda que por pouco tempo, senhor absoluto no meio de seu cativeiro; uma guerrilha cujo ferrete é o interesse particular do chefe e de seus associados, com a avareza e a crueldade por disciplina, há de ser por força brutal no combate, desleal e covarde fora dele!

Esse espírito belicoso que o autor deseja ver nascer aparecerá sem dúvida, mas em uma escala perigosa; o fazendeiro, por exemplo, chefe de uma ou muitas bandeiras, 
quando tiver a sua gente bem aguerrida, tornar-se-á um senhor feudal dentro de sua casa; oprimirá seus vizinhos, zombará das leis e resistirá às autoridades; o autor bem sabe o que neste sentido se pratica em certos pontos do império, e não está ainda desenvolvido o espírito belicoso com a criação das bandeiras.

Depois da guerra, dissemos nós, o autor quer para os índios a escravidão, mas não tendo coragem de pedi-la abertamente, disfarça-a, acrescentamos, com o nome de tutela ou protetorado. Em verdade, quem será tão ingênuo que não compreenda o que é uma tutela desse gênero, que recebe por paga o serviço do tutelado? Não é assim uma coisa semelhante a essa distribuição de africanos chamados livres que se fazia aqui há tempos no Rio de Janeiro quando era capturado algum navio negreiro? O que é um tutor com direito ao trabalho do tutelado? Um senhor julga-se autorizado a exigir de um escravo a maior soma de trabalho possível, trabalho pesado, constante, insuportável; se não é satisfeito, castiga-o cruelmente, e muitas vezes esse escravo não Ihe tem custado senão uma insignificante soma. Calcule-se agora que quantidade e que qualidade de trabalho não se julgará autorizado a exigir um tutor de um tutelado que lhe custou as fadigas da luta e o risco da vida? Se não for satisfeito, tem o direito de obrigá-lo, de castigá-lo. E não sabe o autor o que é o castigo domesticamente aplicado ao índio robusto das florestas? É prender-lhe as mãos, os pés, e muitas vezes a cabeça em um instrumento chamado tronco; é amarrá-lo de braços para trás à roda de um serviço; é escrever-lhe por todo o corpo a golpes de azorrague a sentença de uma degradação eterna!!

A história aí está para atestar o que dizemos: não é, como bem conhece o autor, nova a ideia de bandeiras; todos os que viram ou leram alguma coisa sobre a questão sabem que nunca aproveitam elas senão como meio de destruição; mesmo o autor fazendo o seu elogio, em vez de dizer-nos (e não o faz porque seria mentir) "por este meio se reduziu à civilização esta ou aquela tribo", diz-nos com verdade "por este sistema se deu quase cabo do indômito caiapó".

O autor, apesar de conhecer os princípios liberais e os sentimentos de bom senso do publicista Vatel, não o acha muito humano, e pede que o sejamos nós mais do que ele; quer que eduquemos à força os nossos selvagens, e que quinze anos depois, quando já não precisem mais de tutela, façamos deles prestantes cidadãos e bons cristãos!

Não podemos conter a indignação diante de semelhante doutrina; é o maior escândalo que se pode fazer ao bom senso!... Quinze anos de humilhação, quinze anos de sujeição aos ferros, ao tronco, ao azorrague, para fazer um bom cidadão! Há de ser realmente um cidadão digno de toda a consideração aquele que se apresentar na socie- 
dade com o corpo lanhado pelo azorrague, embrutecido pelos maus-tratos, arrastando consigo as cadeias de quinze anos de escravidão! Não se diga que carregamos aqui a pena; que isso não há de suceder, porque as tutorias só serão dadas a pessoas de reconhecida probidade. Todos conhecem o poder dos hábitos e dos costumes; estão entre nós em maioria as pessoas que sendo de um trato social o mais delicado, incapazes de se envolverem em transações menos honestas, bons e devotos cristãos, tratam com uma dureza bem censurável seus subordinados e escravos. O que acabamos pois de apontar é a consequência inevitável dos princípios que impugnamos. Deus nos livre que o autor seja atendido em suas pretensões a este respeito.

Terminamos pedindo-lhe que renegue em bem da humanidade essas doutrinas que prega, e que se compenetre das palavras que servem de epígrafe a este artigo: elas são do homem talvez o mais sábio que possui hoje o mundo.

Manoel Antônio de Almeida, aluno da Escola de Medicina. 